\title{
IT 技術者におけるソーシャルスキルのストレス緩衝効果
}

\author{
$\bigcirc$ 田中健吾 ${ }^{1}$ \\ ( ${ }^{1}$ 大阪経済大学経営学部) \\ キーワード：ソーシャルスキル，ストレス緩衝効果，IT 技術者
}

\begin{abstract}
Stress-buffering effects of social skills among Japanese software engineers
\end{abstract}
Kengo TANAKA ${ }^{1}$

( ${ }^{1}$ Faculty of Business Administration, Osaka University of Economics)

Key Words: social skills, stress-buffering effects, software engineers

\section{目 的}

IT 技術者が急増する中, 彼らの置かれている特異な就労環 境が, 種々の心理社会的問題をもたらすことが懸念されてい る(櫻田, 2016)。しかし,この業種に固有のストレッサーに起 因する心理的ストレス反応の低減要因に関する研究は多くな い。そこで本研究では，持ち場が頻繁に変わり，対人関係を 良好に保つことが難しい職務環境であることなどの，IT 技 術者に特異的なストレッサーを踏まえ, ソーシャルスキルの ストレス緩衝効果について検討することした。職業性ストレ ス研究において，ソーシャルスキルはコーピングの資源と位 置づけられ，ソーシャルサポートを高めることで，種々のス トレス緩衝効果をもたらすことが示されている(田中, 2009)。

\section{方 法}

調査対象:2017 年 3 月時点で, (株) ネオマーケティングの Web 調查サイト “i Research” 登録者から無作為抽出した 26, 779 名に調査依頼を配信したところ, 10, 076 名が応諾した (回収率 $37.6 \%$ )。18一65 歳の正規雇用者で, IT 技術者の職に ある 579 名から回答を得た(有効回答率 100\%)。このうち, 無 作為抽出した男性 464 名 (平均年齢 45.8 歳, $\mathrm{SD}=8.84$ ) を分析 対象とした。

調査票：IT 技術者用ストレッサー尺度（田中・高原，2017）, ソーシャルスキル尺度（田中，2009），心理的ストレス反応尺 度（田中，2012）を使用した。ストレッサー尺度は，「仕事の 量的負荷」,「長期的展望のなさ」,「不安定な立場」の 3 下位 尺度得点を合計した得点を，心理的ストレス反応尺度は，「疲 労感」, 「易怒感」, 「身体不調感」,「抑うつ感」の 4 下位尺度 得点を合計した得点を分析に使用した。ソーシャルスキル尺 度は,「トラブルシューティングスキル」,「マネジメントスキ ル」,「コミュニケーションスキル」の各下位尺度で測定され る下位スキル別に検討した。

\section{結 果}

各下位スキル別に，ストレッサーとスキルおよび両者の交 互作用項を独立変数とし, 心理的ストレス反応（合計得点） を従属変数とする階層的重回帰分析を行った。ストレッサー
の主効果は全ての分析で有意であり, IT 技術者に特異なスト レッサー得点が高いほど, 心理的ストレス反応得点が高いこ とを示していた。ソーシャルスキルの効果に注目すると， 3 つの下位スキルすべてにおいて有意な主効果が認められた。 また，ストレッサーとコミュニケーションスキルの交互作用 が有意であり，ストレッサーとトラブルシューティングスキ ルの交互作用が有意傾向を示した（Table1）。各下位スキル別 の心理的ストレス反応緩衝効果は, Figure1 に示した。

Table1 階層的重回帰分析結果の概要

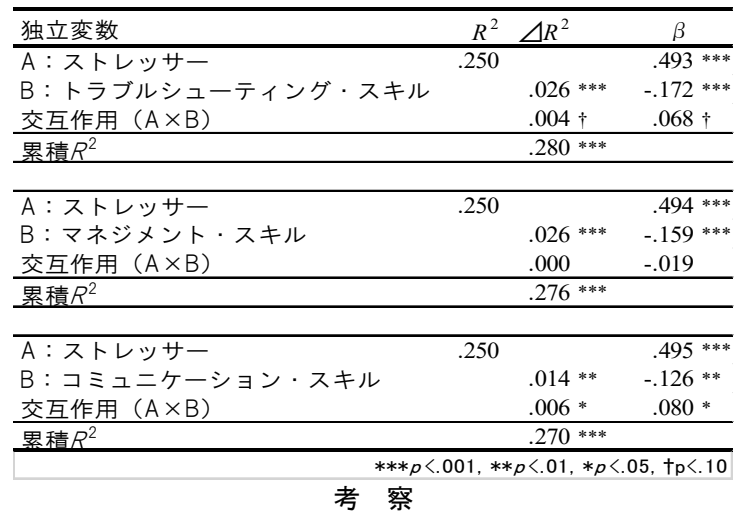

以上より, IT 業に特有のストレッサーに起因する心理的ス トレス反応に対して，3 種のソーシャルスキルが緩衝効果を もたらすことが示された。業務遂行に直結するマネジメント スキルでは主効果のみが認められたが, 日常のコミュニケー ションに機能するスキルや対人葛藤処理に関するスキルにつ いては, ストレッサーの自覚が低い状況での効果について, 交互作用の点から検討する必要がると思われる。

\section{引用文献}

櫻田武嗣 2016 わが国の IT 産業の実態 一般社団法人情 報通信医学研究会編 IT 技術者の長寿と健康のために 近
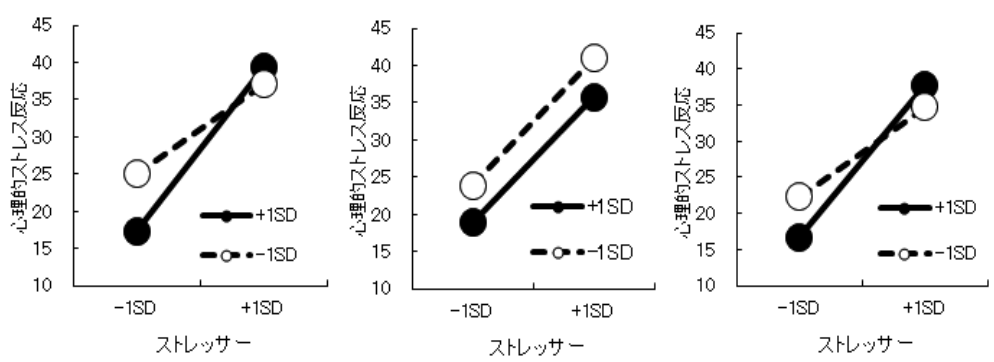
代科学者 pp133-146. 田中健吾 2009 ソーシャルスキル と職業性ストレス:企業従業員の臨床 社会心理学的研究, 晃洋書房, 京都. 田中健吾 2012 勤労者を対象とし た心理的ストレス反応尺度の項目反 応理論による検討 大阪経大論集, 63 , 137-150.

田中健吾・高原龍二 2017 IT 技術 者用ストレッサー尺度の信頼性・妥当 性の検討 日本パーソナリティ心理 学会第 26 回大会発表論文集, 印刷中.

Figure 1 ソーシャルスキルのストレス緩衝効果

（※左から、トラプルシューテインクススキル, マネジメントスキル、コシュニケーションスキル） 